\title{
Academic Patenting: How Universities Use Intellectual Property to Boost Research and Technology Transfer
}

\author{
Petr ZDŘÁLEK, Petra MAREŠOVÁ \\ University of Hradec Králové, Hradec Králové, Czech Republic \\ \{petr.zdralek, petra.maresova \}uhk.cz
}

\begin{abstract}
Universities and other public research organizations are increasingly protecting their inventions. The rise in university patenting has occurred against a broader policy framework aimed at fostering a greater interaction between public research and industry in order to increase the social and private returns from public support to $R \& D$. Making universities and other public research organizations more active in protecting and exploiting their IP means not only actively promoting faculty and student research, but also determining how best to pursue any relationship with business clients while protecting the public interest. The key question, however, is: which is the best channel for transferring the technology to the marketplace regarding to public interest? The current way research and innovation is handled by many Universities is not particularly likely to lead to success because. Privat sector become involved too late in the process and Universities do not get the market input that is essential prior to decided what basic research to translate into innovations. The key question, however, is: which is the best channel for transferring the technology to the marketplace regarding to public interest? It has been used a method of literature review of available sources exploring research studies and current website sources, where the experts' statements in this area are described, and a method of comparison and evaluation of their findings.
\end{abstract}

Keywords: University, Intellectual Property, Technology Transfer.

\section{Introduction}

Universities and other public research organizations are increasingly protecting their inventions. The rise in university patenting has occurred against a broader policy framework aimed at fostering a greater interaction between public research and industry in order to increase the social and private returns from public support to R\&D. The aim of this paper is description of possibilities how universities can use their intellectual property to boost research and technology transfer to private sector. The most of universities's inventions will never emerge from "the Valley of Death." So why universities wants to holds on to its technology unless there are up-front payments that skews the cycle, puts burdens on start-ups when they need help and doesn't fuel the job growth and economic development potential? The current way research and innovation is handled by many Universities is not particularly likely to 
lead to success because, companies become involved too late in the process and Universities do not get the market input that is essential prior to decided what basic research to translate into innovations [9].

Think of the Value Hierarchy as a pyramid with five levels. Each level represents a different expectation the company has about the contribution that its IP/IA function should be making to the corporate goals. Each higher level on the pyramid represents the increasing demands placed upon the IP function by the executive team and the board of directors. Like building blocks, each higher level relies on the foundation of the lower levels. Mastery of the practices, characteristics, and activities of the prior levels builds the foundation for greater increases in shareholder value at the next level [2].

In case of university can be speak about sixth level of pyramid. This level represents open access to university patents. The global movement for open access to publicly-funded research stems from the sensible proposition that if the government has used taxpayers' money to fund research, the publication of the results of that research should be freely-licensed [4]. Hundreds of universities around the world have adopted open access policies asking faculty to publish their research in open access journals or archive them in open repositories [3]. As the open access movement continues to grow and mature, it can be hoped to see open access allies on campus begin to take on their institutions' patenting policies. University patenting and licensing policies directly affect how researchers' outputs will be used in the field. The same arguments that have given way to the explosion of open access publishing also apply to patents-just as researchers shouldn't trust their work with publishers that don't have the public's interest at heart, their institutions shouldn't sell patents to trolls out for nothing but a quick buck or get ,another money” from government. Instead, they should partner with companies that will bring their inventions to the public [3].

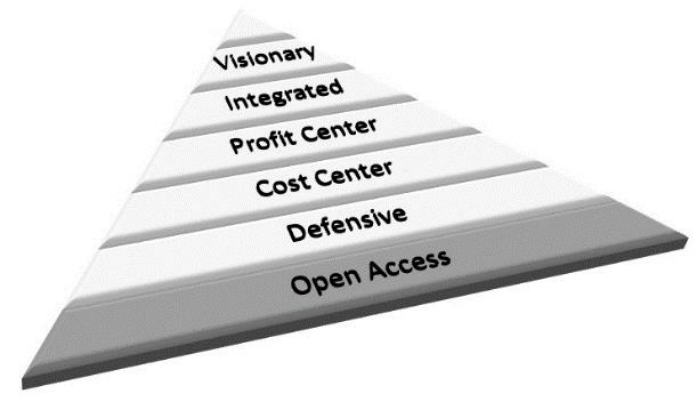

Fig. 1. The patent value hierarchy [2]

\section{Methods}

The authors used a method of literature review of available sources exploring research studies and current website sources, where the experts' statements in this area are 
described, and a method of comparison and evaluation of their findings. In addition, the results of previous research are used to deduce the new technology transfer approach to make the most effective use of results in the private sector.

\section{$3 \quad$ Analysis of Academic Patenting}

\subsection{Role of universities and university patenting}

The general strengthening of intellectual property protection world-wide as well as the passage of legislation aimed at improving technology transfer are additional factors that have facilitated the expansion of patenting in academia. Encouraging universities to commercialize research results by granting them title to IP can be useful but it is not sufficient to get researchers to become inventors. The key is that institutions and individual researchers have incentives to disclose, protect and exploit their inventions. Given the diversity of research institutions and traditions, it is important that incentives are set at the institution level, but national guidelines can help bring about coherence and the sharing of good practices. As important as incentives is the need for research institutions to clarify IP rules and disseminate them among faculty, staff as well as graduate students- who are increasingly involved in public research activities. To bridge the gap between invention and commercialization, universities have established "technology transfer offices" (TTOs) that carry out a wide range of functions, from licensing patents to companies to managing research contracts. The majority appear to be dedicated on-site institutions and integrated into the university or research institution. Many of the TTOs are in their infancy; most are less than 10 years old and have less than five full-time staff. Still, the number of new TTOs is growing, to the order of 1 per year per institution. Income from licensing academic inventions remains quite small in comparison to overall research budgets. Academic patenting is thus more about boosting research and transferring technology to industry than about making a profit. A main barrier to the development of TTOs is access to experienced technology transfer professionals. Not only are the skills sets of such professionals in short supply but sometimes government employment rules and pay-scales prevent public institutions from being able to provide competitive salaries to such professionals. Governments are nevertheless trying to help universities build IP management capacity. One of the questions facing technology transfer managers and inventors is whether to license a technology or to create a start-up firm to commercialize it. Governments and university managers, especially in some European countries, have tended to favour start-ups as opposed to licensing strategies. Part of this stems from the rise in government funded venture funds that aim to promote new firm creation. The key question, however, is: which is the best channel for transferring the technology to the marketplace? The answer in fact depends on the technology in question, the market for such a technology, the skills set of the staff and researchers involved the invention, access to venture capital, and finally the mission of the institution. Certain "platform" technologies with a wide range of applications may be commercialized via 
a start-up company for example while others may be licensed to larger firms with the business capacity to develop the invention further and integrate it into its $R \& D$ and business strategy. As academic inventions arise in areas closer to basic research, scientists and policy makers are also concerned that patenting certain inventions could block downstream research. One example is that of research tools, in which granting a patent could inhibit diffusion by increasing the costs and difficulty of use such tools in applied research. In response, the National Institutes of Health in the United States (NIH) have espoused a policy that discourages unnecessary patenting and encourages non-exclusive licensing (see link). Such guidelines are now being emulated by funding agencies and research institutions in other countries [1].

\subsection{Technology Transfer Approach}

Technology transfer is about relationships and collaboration among individuals and groups (industry, government, and academia) with varied interests [7]. Classical technology transfer approach: Research - invention developed - legal protection identify partners negotiate - license. This model of university patenting has many disadvantageous: time consuming and at the expense of societal impact, limited possibilities getting idea to product and identify potential partners. Many great scientific breakthroughs cannot be commercialized through patenting. Some inventions are never licensed out due to unable to identify potential partners or invention is result of basic research and hasn't any commercial potential. Sometimes failed negations because potential partner finds inventions too high risk or terms have not been successful negotiated [5].

\subsection{Valleys of Death of Technology Transferring}

In technology transfer, the "valley of death" is the metaphor often used to describe the gap between academic-based innovations and their commercial application in the marketplace. Although traditional definitions of technology transfer often assume a smooth shift of intellectual property from university (or private) research laboratories to private or publicly held companies that commercially develop the technology, the valley of death suggests that the practice is anything but smooth. In fact, this rather grim metaphor implies that academic research is in some way cut off from the outside world [6]. 


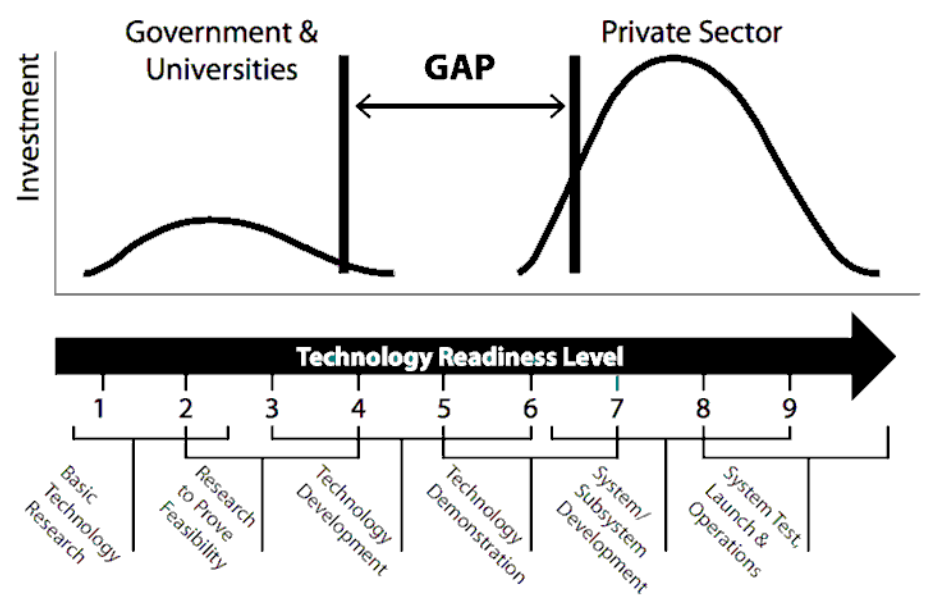

Fig. 2. The gap in manufacturing and innovation. [8]

\section{New Technology Transfer Models}

Many Universities do not properly invest in technology transfer and instead see technology transfer as a vehicle to return funds quickly, rather than viewing the licensing out of University innovations as a long term endeavor [8]. Universities find it very difficult to be successful in technology transfer because I believe they have adopted business models that have not been sustainable. It is very costly for an institute to go and file for patents and yet there are not very clear feedback loops that bring back to institutions to sustain these operations. So Universities quickly find it extremely expensive to sustain their own tech transfer offices, and they are under extreme pressure to produce funding early as opposed to making investments toward those activities and seeing those investments as long term [8]. 


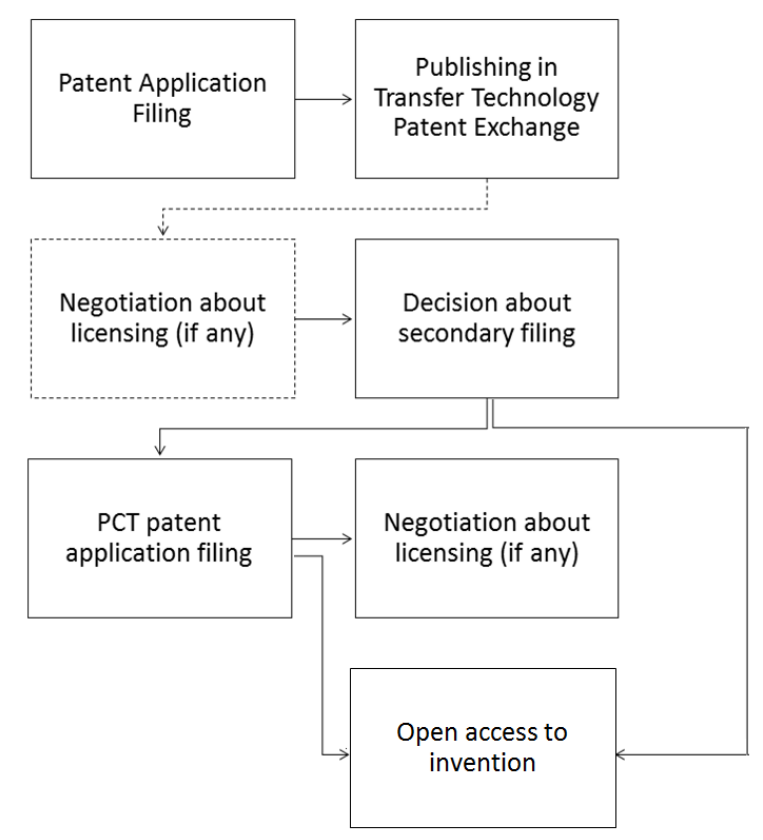

Fig. 3. New technology transfer approach.

New approach of university patenting in some country should be require to stimulate translational research with industry (Fig 3).

\section{Conclusion}

The way how to increase the commercial potential and overcame gap between research and production is publishing of invention as soon as is possible. The way to do is use own database designed to be modular so that transfer offices tailor their intellectual asset management solution to the unique needs of technologic transfer organization. It can be called as Transfer Technology Patent Exchange (TTPE) where transfer office is trying to find a partner for commercialization of invention. TTPE can be defined as informal database where the university can share as much information about invention as is possible before publishing in official databases. It can help transfer offices to identifying potential licensees during priority period. It can be very helpful for planning, budgeting and decision making about secondary filling during first year of patent application's life. If some potential customer/partner will appear during priority period, on the base of negations, the patent rights can be sold or licensed. If any potential partner will not appear, the university should decide about PCT patent application filing or invention should be offer on the base of open access principles to all stakeholders, because keep patent protection only in one country has 
absolutely no reason and it is only limitation for domestic entities, because inventions are on other territories freedom to operate.

Acknowledgements. The paper was created with the support of the internal specific research titled "Evaluation of Investments in the Industry 4.0 Concept" of the Faculty of Informatics and Management of the UHK.

\section{References}

1. Cervantes, M.: Academic Patenting: How universities and public research organizations are using their intellectual property to boost research and spur innovative start-ups. WIPO Small and Medium-sized Enterprises Documents (2003).

2. Davis, J. L., Harrison, S. S.: Edison in the boardroom: How leading companies realize value from their intellectual assets (Vol. 28). John Wiley \& Sons (2002).

3. Harmon, E.: Patent Trolls Undermine Open Access. Available on: https://www.eff.org/deeplinks/2016/10/patent-trolls-undermine-open-access, last accessed 2017/10/26

4. Malcolm, J. : Public Money, Public Code: Show Your Support For Free Software in Europe. Available on: https://www.eff.org/deeplinks/2017/10/public-money-public-codeshow-your-support-free-software-europe, last accessed 2017/06/26

5. Smailes, B.: Partner, Gunn\&Twynmore. Have we forgotten what we are supposed to do? Can we do TT faster, smarter and more effectively? Annual CEE Conference co-organized by LES Czech Republic, LES Austria and LES Hungary. 1 October 2015, Prague. The innovation conundrum: Getting idea to product and product to market.

6. Gulbrandsen, K. E.: Bridging the valley of death: The rhetoric of technology transfer. Iowa State University (2009).

7. Coppola, N.: Communicating green innovation technology: Transfer in a universitybusiness-government consortium. Comparative Technology Transfer and Society, 5, 233-252 (2007).

8. Holton, D.: Technology Transition: Key Ingredient to Ensuring Manufacturing Innovation Through NNMI Institutes (2014).

9. Quinn, G.: In Search of Technology Transfer Best Practices: A Conversation with UC Davis Chancellor Linda Katehi.Abailable on: http://www.ipwatchdog.com/2010/05/09/insearch-of-technology-transfer-best-practices-a-conversation-with-uc-davis-chancellorlinda-katehi/id=10425, last accessed 2017/010/26/, last accessed 2017/10/26 